\title{
Complete Amino Acid Sequence of Luffin-a, a Ribosome-inactivating Protein from the Seeds of Sponge Gourd (Luffa cylindrica) ${ }^{\dagger}$
}

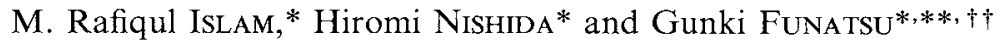 \\ * Laboratory of Biochemistry and ** Laboratory of Protein Chemistry \& Engineering, \\ Faculty of Agriculture, Kyushu University, Fukuoka 812, Japan
}

Received June 1, 1990

\begin{abstract}
The complete amino acid sequence of Iuffin-a has been determined. Twenty-two peptides were isolated from the tryptic digest of luffin-a and sequenced employing the DABITC/PITC double coupling method. Overlaping of these peptides was achieved by analyzing the chymotryptic peptides or CNBr-fragments of Iuffin-a and their $S$. aureus V8 protease peptides. Luffin-a consists of 248 amino acid residues and its relative molecular mass is calculated to be $27,021 \mathrm{Da}$, excluding the attached sugar chains reasoned to be present at each Asn residue of positions 28, 33, 77, 84, 206, and 227. A comparison with the sequence of ricin A-chain showed $33 \%$ sequence identity indicating that these proteins are homologous.
\end{abstract}

Many higher plants contain proteins that inhibit protein synthesis in eukaryotic cells. ${ }^{1-3)}$ In recent years, it has been shown that these proteins inactivate eukaryotic ribosomes by enzymatically cleaving off a specific adenine residue $\left(A_{4324}\right)$ from $28 \mathrm{~S}$ rRNA of the $60 \mathrm{~S}$ ribosomal subunit. ${ }^{4,5)}$ Seeds of the sponge gourd (Luffa cylindrica) have been shown to contain protein of such a nature and was named "Iuffin" by Kishida et al. ${ }^{6)}$ Recently we isolated two isoforms of luffin ( $a$ and $b)^{7)}$ and briefly reported the complete amino acid sequence of luffin-a. ${ }^{8)}$ In this paper we describe the experimental details leading to the elucidation of the complete sequence and a sequence comparison of luffin-a with ricin A-chain, a ribosome-inactivating protein (RIP) from the seeds of castor bean (Ricinus communis). ${ }^{9)}$

\section{Materials and Methods}

Luffin-a was prepared from sponge gourd seeds (Takii
Seed Co.) as described previously. ${ }^{7)}$ TPCK-treated trypsin and chymotrypsin were purchased from Sigma Chemicals. S. aureus $\mathrm{V} 8$ protease and carboxypeptidase $\mathrm{Y}$ were from INC ImmunoBiochemmicals and Oriental Yeast Co., Ltd., respectively. Cyanogen bromide $(\mathrm{CNBr})$ was from Nakarai Chemicals $\mathrm{Co}$. All other reagents were of analytical grade.

Preparation of succinylated luffin-a. To $15 \mathrm{mg}$ of luffin-a in $1 \mathrm{ml}$ of $0.5 \mathrm{M} \mathrm{NaCl}, 0.9 \mathrm{mg}$ of succinic anhydride was added in $15 \mathrm{~min}$. The reaction mixture was incubated at $15^{\circ} \mathrm{C}$ for $1 \mathrm{hr}$ and then dialyzed against deionized water. Analysis of free amino groups of the product showed that the succinylation of luffin-a was not complete.

Proteolytic digestion. The lyophilyzed luffin-a $(5 \mathrm{mg})$ was dissolved in $0.5 \mathrm{ml}$ of formic acid, dialyzed sufficiently against deionized water, and then digested with $0.1 \mathrm{mg}$ trypsin at $\mathrm{pH} 8.0$ (adjusted with dilute ammonia) and $37^{\circ} \mathrm{C}$ for $7 \mathrm{hr}$. The digest was separated into a soluble fraction (Ts-fraction) and pellet (Tp-fraction) by centrifugation. The Tp-fraction was further digested with $30 \mu \mathrm{g}$ trypsin for $4 \mathrm{hr}$ and again separated into soluble fraction (Tps-fraction) and pellet (Tpp-fraction).

Succinylated luffin-a was dissolved in $6 \mathrm{M}$ guanidine- $\mathrm{HCl}$, dialyzed against deionized water, and then digested with trypsin in the same manner as above. A precipitate

+ This work was supported in part by a Grant-in-Aid for Scientific Research from the Ministry of Education, Science and Culture of Japan.

it To whom correspondence should be addressed.

Abbreviations: RIP, ribosome-inactivating protein; DABITC, 4- $N, N$-dimethylaminoazobenzene 4'-isothiocyanate; PITC, phenylisothiocyanate; RP-HPLC, reverse-phase high-performance liquid chromatography; TFA, trifluoroacetic acid; $\mathrm{MeCN}$, acetonitrile; $\mathrm{PrOH}$, propanol. 
(STp-fraction) produced upon digestion was separated from soluble fraction (STs-fraction).

Chymotryptic digestion was done using $1 / 100$ by weight of the enzyme in aqueous solution at $\mathrm{pH} 8.0$ (adjusted with dilute ammonia) and $37^{\circ} \mathrm{C}$ for 1 to $1.5 \mathrm{hr}$. In case of luffin-a, the protein was pretreated as described in tryptic digestion. Digestion with V8 protease was performed in $50 \mathrm{~mm}$ ammonium bicarbonate using $3 / 100$ by weight of the enzyme at $37^{\circ} \mathrm{C}$ for $20 \mathrm{hr}$ and the digest was separated into a soluble fraction (Vs-fraction) and pellet ( $\mathrm{Vp}$-fraction) by centrifugation.

Digestion of luffin-a ( $1 \mathrm{mg}$ ) with carboxypeptidase $\mathrm{Y}$ was done in $1.5 \mathrm{ml}$ of $0.1 \mathrm{M}$ pyridine-acetate buffer, $\mathrm{pH} 5.6$, containing $0.2 \%$ SDS at room temperature with $1 / 100$ by weight of the enzyme. ${ }^{10}$ )

CNBr-cleavage. CNBr-cleavage of Iuffin-a was done in $80 \%$ TFA with a 200 -fold molar excess of CNBr over methionine by the method of Schroeder et al. ${ }^{11)}$ for $24 \mathrm{hr}$ at room temperature.

Gel filtration on Bio-Gel P-30. The lyophilized CNBr-cleaved luffin-a was dissolved in $50 \%$ formic acid containing a small amount of 2-mercaptoethanol, put on a Bio-Gel P-30 column $(2.1 \times 98 \mathrm{~cm})$ and developed with $50 \%$ formic acid.

Peptide separation. Peptide separation was performed by reverse-phase HPLC (RP-HPLC) (JASCO TWINCLE) with a Finepak $\mathrm{C}_{4}$ or $\mathrm{C}_{8}$ column $(4.6 \times 250 \mathrm{~mm})$ or an Asahipak $C_{18}$ column $(5.5 \times 150 \mathrm{~mm})$ using a linear gradient from Solvent A to Solvent B. The solvent systems used were ${ }^{12,13)}$ : system I, $5 \mathrm{~mm}$ phosphate buffer, $\mathrm{pH} 6.0$ (Solvent A) and 60\% MeCN in Solvent A (Solvent B); system II, $0.1 \%$ TFA (Solvent A) and $60 \% \mathrm{MeCN}$ in Solvent A (Solvent B); system III, 0.1\% TFA (Solvent A) and $30 \% \mathrm{MeCN}$ in 2-PrOH (Solvent B); system IV, $5 \mathrm{mM}$ ammonium bicarbonate (Solvent $\mathrm{A}$ ) and $80 \% 2-\mathrm{PrOH}$ in Solvent A (Solvent B).

Amino acid composition and amino acid sequence analysis. Amino acid compositions of the peptides were analyzed by hydrolyzing samples in evacuated sealed tubes at $108^{\circ} \mathrm{C}$ for $24 \mathrm{hr}$ using constant-boiling $\mathrm{HCl}$ containing $0.05 \%$ 2-mercaptoethanol. The hydrolysates were analyzed with a Hitachi automated amino acid analyzer (Type 655A). Tryptophan content of the peptide was measured by the absorption at $280 \mathrm{~nm}$ in the characteristic extinction curve (320-220 nm) using $E_{280}^{1 \mathrm{~cm}}=5500 \mathrm{M}^{-1} \mathrm{~cm}^{-1}$. For composition of luffin-a, hydrolysates of 24,48 , and $72 \mathrm{hr}$ were analyzed and the tryptophan content was determined by the method of Edelhoch. ${ }^{14)}$ Cysteine content was measured by analyzing performic acid oxidized luffin-a.

The peptides were sequenced using the DABITC/PITC double coupling method. ${ }^{15,16)}$ The $\mathrm{C}$-terminal residue of the peptide ending in lysine was identified by the composition difference.
Computer analysis. Sequences were compared on a FACOM M780 computer using the program ALIGN. ${ }^{17)}$ A mutation data matrix with a break penalty of 10 was used for the scoring.

Nomenclature of peptides. Tryptic peptides, chymotryptic peptides, and $\mathrm{CNBr}$-fragments from luffin-a, tryptic peptides from succinylated luffin-a, and V8 protease peptides from CB-III fragment are designated as $\mathbf{T}, \mathrm{CH}$, $\mathrm{CB}$, ST, and $\mathrm{V}$, respectively, followed by a number corresponding with their order in the sequence. Chymotryptic peptides from the tryptic peptides or $\mathrm{V} 8$ protease peptides are $\mathrm{C}$.

\section{Results and Discussion}

\section{Amino acid composition and terminal sequences of luffin-a}

Analysis of 24,48 , and $72 \mathrm{hr}$ hydrolysates from luffin-a gave the amino acid composition of $\mathrm{Asp}_{23.0(23)} \mathrm{Thr}_{22.9(23)} \mathrm{Ser}_{28.9(29)} \mathrm{Glu}_{20.3(20)}$ Pro $_{6.1(6)} \mathrm{Gly}_{14.3(14)} \mathrm{Ala}_{22.4(22)} \mathrm{Val}_{16.7(17)}$ Met $_{1.9(2)}$ Ile $_{17.5(18)}$ Leu $_{26.1(26)} \mathrm{Tyr}_{12.9(13)}$ Phe $_{10.2(10)}$ Lys $_{15.9(16)}$ His $_{1.3(1)}$ Arg $_{7.32(7)}$ $\operatorname{Trp}_{0.91(1)} \mathrm{Cys}_{0.13(0)}$.

The N-terminal sequence of luffin-a was Asp-Val-Arg-Phe-Ser-Leu-Ser-Gly-Ser-SerSer-. Digestion of luffin-a with Cpase Y released $0.35 \mathrm{~mol}$ of Ala in $10 \mathrm{~min}, 0.53 \mathrm{~mol}$ of Ala and $0.28 \mathrm{~mol}$ of Val in $20 \mathrm{~min}$, and $0.6 \mathrm{~mol}$ of Ala and $0.45 \mathrm{~mol}$ of Val in $30 \mathrm{~min}$ per mol of protein, indicating the C-terminal sequence of -Val-Ala.

\section{Amino acid sequence of tryptic peptides from luffin-a}

The Ts- and Tps-fractions from the tryptic digest of luffin-a were chromatographed by RP-HPLC on a $\mathrm{C}_{4}$ column using solvent systems I and III, respectively, and the Tpp-fraction was resolved on an Asahipak $\mathrm{C}_{18}$ column using solvent system IV (Fig. 1). Each peak from Ts-fraction gave a pure peptide except peak 13, which was separated into two peptides (T-2 and T-7) by RP-HPLC on the same column using solvent system II. The Tpp-fraction yielded two main peaks corresponding to two large peptides, T-6 and T-12. The Tps-fraction was eluted into a number of peaks, but only peak 8 contained a new peptide, 

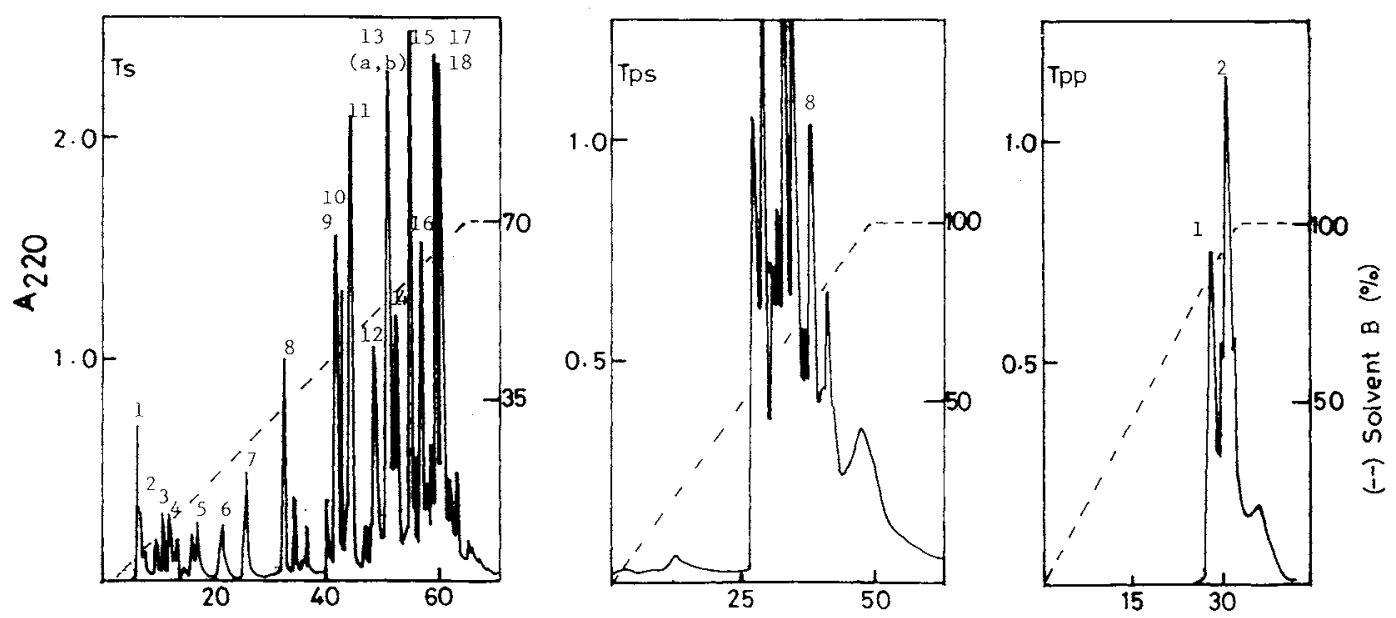

\section{Retention Time (min)}

Fig. 1. RP-HPLC of the Tryptic Peptides in Ts-, Tps-, and Tpp-fractions from Luffin-a.

The peptides in Ts- and Tps-fractions were resolved on a Finepak $\mathrm{C}_{4}$ column using solvent system I consisting of $5 \mathrm{~mm}$ phosphate buffer, pH 6.0 (solvent A) and $60 \% \mathrm{MeCN}$ in the same buffer (solvent B), and systern III consisting of $0.1 \%$ TFA (solvent A) and 30\% MeCN in 2-PrOH (solvent B), respectively. The peptides in Tpp-fraction was separated on an Asahipak $\mathrm{C}_{18}$ column using solvent system IV consisting of $5 \mathrm{~mm}$ ammonium bicarbonate solution (solvent $\mathrm{A}$ ) and $80 \% 2-\mathrm{PrOH}$ in the same solution (solvent $\mathrm{B}$ ).

$\mathrm{T}-4$, which was not found in Ts- or Tpp-fractions. Thus a total of 22 peptides (T-1-T-22) were isolated from the tryptic digest of luffin-a. The amino acid compositions of these peptides are listed in Table I.

Amino acid sequencing of the tryptic peptides except T-4, T-6 and T-12 was accomplished directly by the DABITC/PITC method. Peptides T-4, T-6, and T-12 were further digested with chymotrypsin and the resulting peptides were separated by RP-HPLC on a $\mathrm{C}_{8} / \mathrm{C}_{18}$ column using solvent systems II or IV and sequenced, which led to the completion of the sequences of T-4, T-6, and $\mathrm{T}-12$. Total number of amino acid residues of the tryptic peptides comprised 248 residues, identical to that of luffin-a, indicating that all the tryptic peptides had indeed been isolated. The sequences of these peptides are shown in Fig. 6.

\section{Sequence analysis of chymotryptic peptides from} luffin- $a$

Figure 2 shows the RP-HPLC pattern of the chymotryptic peptides from luffin-a on a $\mathrm{C}_{4}$

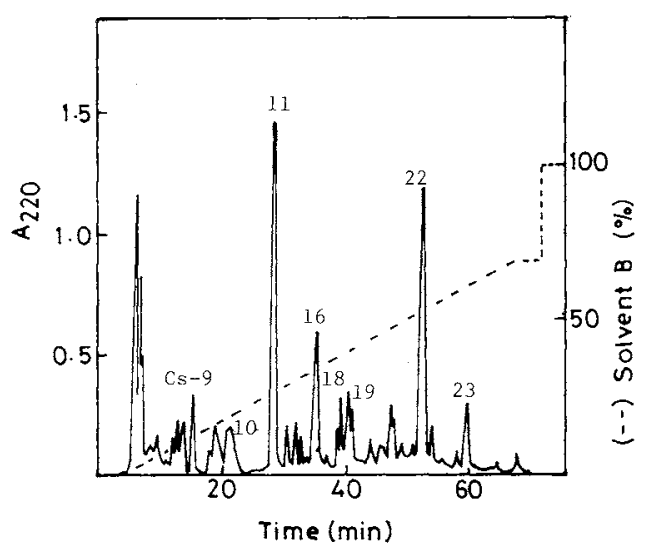

Fig. 2. RP-HPLC of the Chymotryptic Peptides from Luffin-a.

The digest was put on a Finepak $\mathrm{C}_{4}$ column and eluted with solvent system I as indicated in Fig. 1.

column employing solvent system I. After rechromatography, eight lysine- or/and arginecontaining peptides (CH-1-CH-8) were obtained (Table II). Sequence analyses of these peptides provided the alignments of (T-1)-(T2)-(T-3)-(T-4), (T-7)-(T-8)-(T-9) and (T-16)(T-17)-(T-18)-(T-19) as can be seen in Fig. 6. 
Table I. Amino Acid Compositions of the Tryptic Peptides from Luffin-a.

The values in parentheses are from the sequence.

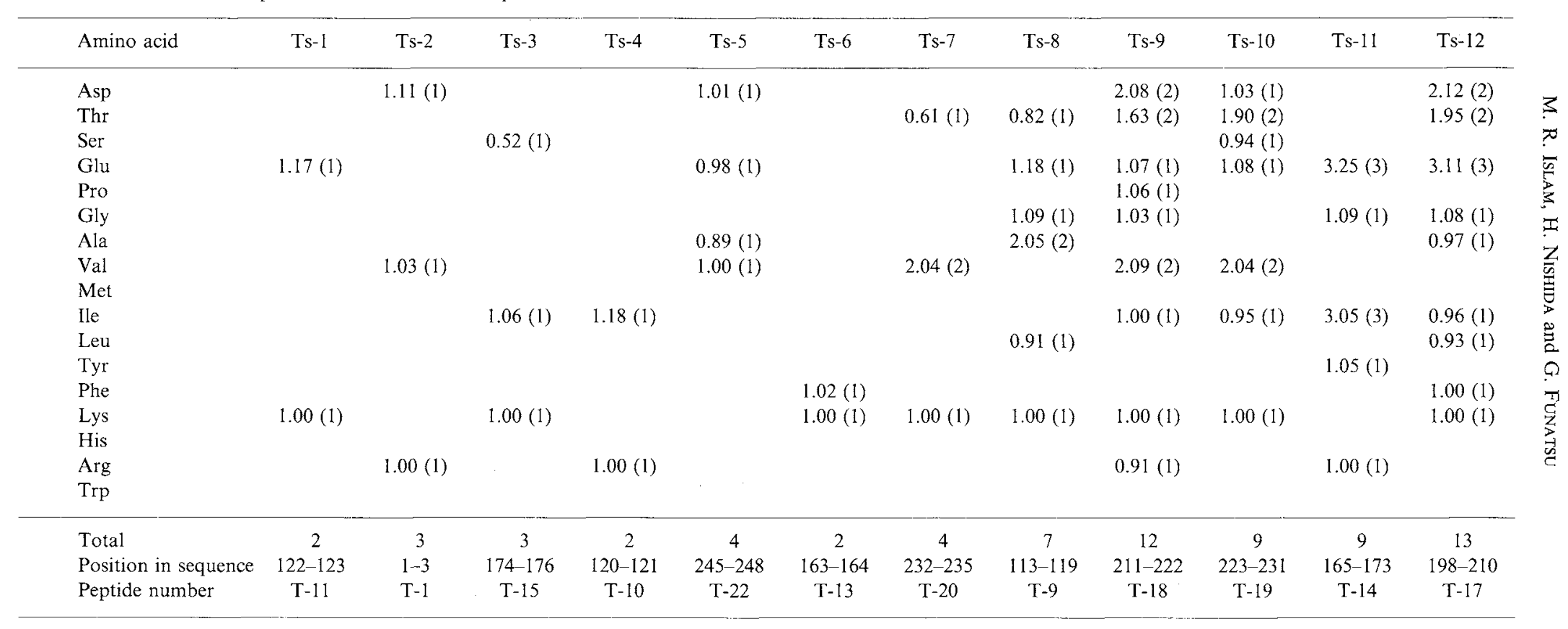


Table I. (Continued).

\begin{tabular}{|c|c|c|c|c|c|c|c|c|c|c|c|}
\hline Amino acid & Ts-13a & Ts-13b & Ts-14 & Ts -15 & Ts- 16 & Ts- 17 & Ts- 18 & Tps- 8 & Tpp-1 & Tpp-2 & Sum \\
\hline Asp & & & $1.17(1)$ & $1.23(1)$ & $2.01(2)$ & $2.03(2)$ & $2.06(2)$ & $2.15(2)$ & $4.00(4)$ & $2.11(2)$ & 23 \\
\hline Thr & & $0.80(1)$ & & $1.61(2)$ & $1.92(2)$ & $0.94(1)$ & & $1.88(2)$ & $2.02(2)$ & $4.58(5)$ & 23 \\
\hline Ser & $0.61(1)$ & $6.29(7)$ & & $1.69(2)$ & $1.02(1)$ & $4.55(5)$ & & $4.96(5)$ & $3.65(4)$ & $3.06(3)$ & 30 \\
\hline Glu & $1.14(1)$ & & & $1.17(1)$ & & $2.23(2)$ & $1.18(1)$ & & $1.93(2)$ & $2.21(2)$ & 20 \\
\hline Pro & & & & $1.07(1)$ & & $0.91(1)$ & & $0.96(1)$ & & $1.76(2)$ & 6 \\
\hline Gly & & $1.17(1)$ & $1.11(1)$ & $1.97(2)$ & $1.19(1)$ & & & $2.23(2)$ & $1.18(1)$ & $1.26(1)$ & 13 \\
\hline Ala & $0.96(1)$ & & & & & $2.01(2)$ & & $3.21(3)$ & $3.21(3)$ & $8.69(9)$ & 22 \\
\hline Val & $1.09(1)$ & & & $1.15(1)$ & & $0.98(1)$ & & $0.92(1)$ & $3.84(4)$ & $0.86(1)$ & 17 \\
\hline Met & & & & & $0.95(1)$ & & & & $0.83(1)$ & & 2 \\
\hline Ile & & & $1.08(1)$ & $0.98(1)$ & & $0.86(1)$ & $0.97(1)$ & $1.17(1)$ & $1.74(2)$ & $2.73(3)$ & 18 \\
\hline Leu & $1.01(\mathrm{l})$ & $1.03(1)$ & $1.09(1)$ & $1.03(1)$ & $1.99(2)$ & $3.89(4)$ & $2.92(3)$ & $3.74(4)$ & $2.13(2)$ & $4.76(5)$ & 26 \\
\hline Try & $1.00(1)$ & $0.99(1)$ & & $1.81(2)$ & $1.93(2)$ & & $0.99(1)$ & $0.93(1)$ & $2.61(3)$ & $1: 21(1)$ & 13 \\
\hline Phe & $1.03(1)$ & $1.13(1)$ & $1.08(1)$ & & 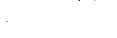 & & & & $1.76(2)$ & $2.83(3)$ & 10 \\
\hline Lys & $1.00(1)$ & $1.00(1)$ & & $1.00(1)$ & $1.00(1)$ & $1.00(1)$ & $1.00(1)$ & $1.00(1)$ & $1.08(1)$ & & 16 \\
\hline His & & & & & & & & & & $0.98(1)$ & 1 \\
\hline Arg & & & $1.00(1)$ & & & & & $1.10(1)$ & & $1.00(1)$ & 7 \\
\hline Trp & & & & & & $0.91(1)$ & & & & & 1 \\
\hline Total & 8 & 13 & 6 & 15 & 12 & 21 & 9 & 24 & 31 & 39 & 248 \\
\hline Position in sequence & $90-97$ & $4-16$ & $17-22$ & $98-112$ & $47-58$ & $177-197$ & $236-244$ & $23-46$ & $59-89$ & $124-162$ & \\
\hline Peptide number & $\mathrm{T}-7$ & $\mathrm{~T}-2$ & $\mathrm{~T}-3$ & $\mathrm{~T}-8$ & $\mathrm{~T}-5$ & T-16 & $\mathrm{T}-21$ & $\mathrm{~T}-4$ & $\mathrm{~T}-6$ & $\mathrm{~T}-12$ & \\
\hline
\end{tabular}


Table II. Amino Acid Compositions of the Selected Chymotrytic Peptides from Luffin-a Numbers in parentheses are from the sequence.

\begin{tabular}{|c|c|c|c|c|c|c|c|c|}
\hline Amino acid & Cs-9 & Cs- 10 & Cs-11 & Cs-16 & Cs- 18 & Cs- 19 & Cs-22 & Cs-23 \\
\hline Asp & $1.08(1)$ & $1.23(1)$ & & & $2.12(2)$ & & $4.00(4)$ & \\
\hline Thr & & & $0.97(1)$ & & $1.16(1)$ & & $4.79(5)$ & $1.82(2)$ \\
\hline Ser & $0.96(1)$ & & $6.56(7)$ & $3.76(4)$ & $1.20(1)$ & $1.05(1)$ & $0.95(1)$ & $1.04(1)$ \\
\hline Glu & $1.11(1)$ & & & & & $2.12(2)$ & $2.16(3)$ & \\
\hline Pro & & & & & $1.04(1)$ & & $1.03(1)$ & $1.00(1)$ \\
\hline Gly & $1.08(1)$ & & $1.15(1)$ & $1.15(1)$ & $2.14(2)$ & & $1.06(1)$ & $1.16(1)$ \\
\hline Ala & & & & $1.99(2)$ & $0.97(1)$ & & & \\
\hline Val & & $0.91(1)$ & & & $0.95(1)$ & & $4.56(6)^{*}$ & $1.69(2)$ \\
\hline \multicolumn{9}{|l|}{ Met } \\
\hline Ile & & & & & $0.84(1)$ & $0.97(1)$ & $2.74(3)$ & 0.87 (1) \\
\hline Leu & $1.05(1)$ & & $1.18(1)$ & $1.01(1)$ & $2.26(2)$ & $1.17(1)$ & $0.76(1)$ & $1.12(1)$ \\
\hline Tyr & $1.00(1)$ & & $1.00(1)$ & $0.95(1)$ & $0.73(1)$ & & & $1.00(1)$ \\
\hline Phe & & $1.02(1)$ & $0.83(1)$ & & & & & $1.13(1)$ \\
\hline Lys & $1.03(\mathrm{I})$ & & $1.12(1)$ & & $1.00(1)$ & $1.00(1)$ & $3.81(4)$ & $1.09(1)$ \\
\hline \multicolumn{9}{|l|}{$\mathrm{His}$} \\
\hline Arg & & $1.00(1)$ & & $1.00(1)$ & $0.99(1)$ & & $0.94(1)$ & \\
\hline \multicolumn{9}{|l|}{ Trp } \\
\hline Total & 7 & 4 & 13 & 10 & 15 & 6 & 30 & 12 \\
\hline Position in sequence & $107-113$ & $1-4$ & $5-17$ & $38-47$ & $18-32$ & $196-201$ & $210-239$ & $95-106$ \\
\hline Peptide number & $\mathrm{CH}-6$ & $\mathrm{CH}-1$ & $\mathrm{CH}-2$ & $\mathrm{CH}-4$ & $\mathrm{CH}-3$ & $\mathrm{CH}-7$ & $\mathrm{CH}-8$ & $\mathrm{CH}-5$ \\
\hline
\end{tabular}

* Low yield is due to incomplete hydrolysis of two Val-Val bonds.

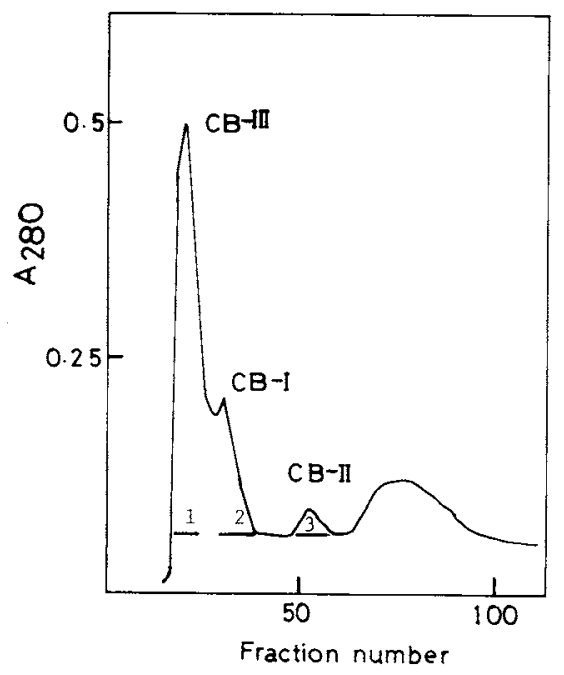

Fig. 3. Gel Filtration of CNBr-fragments from Luffin-a on a Bio-Gel P-30 Column $(2.1 \times 98 \mathrm{~cm})$ in $50 \%$ Formic Acid.

Fractions for the respective fragments were pooled as indicated by the bars. CNBr-fragments are numbered according to their position in the sequence.
Table III. Amino ACID COMPOSLTIONS OF THE CNBr-FraGmENTS OF LUFFin-a

Numbers in parentheses are the nearest integers of the analyzed values. $\mathrm{Hse}=$ homoserine.

\begin{tabular}{lcccr}
\hline Amino acid & CB-I & CB-II & CB-III & Sum \\
\hline Hse & $+(1)$ & $+(1)$ & - & 2 \\
Asp & $4.00(4)$ & $3.12(3)$ & $15.92(16)$ & 23 \\
Thr & $3.61(4)$ & $2.15(2)$ & $17.02(17)$ & 23 \\
Ser & $10.73(11)$ & $1.64(2)$ & $14.70(15)$ & 28 \\
Glu & $0.90(1)$ & $1.06(1)$ & $19.20(19)$ & 21 \\
Pro & $0.94(1)$ & - & $4.85(5)$ & 6 \\
Gly & $3.78(4)$ & $1.18(1)$ & $8.17(8)$ & 13 \\
Ala & $2.90(3)$ & $1.92(2)$ & $13.90(14)$ & 19 \\
Val & $2.12(2)$ & $2.73(3)$ & $12.68(13)$ & 18 \\
Met & - & - & - & - \\
Ile & $1.93(2)$ & $1.81(2)$ & $12.83(13)$ & 17 \\
Leu & $5.67(6)$ & $1.70(2)$ & $14.75(15)$ & 23 \\
Tyr & $2.13(2)$ & $1.69(2)$ & $7.65(8)$ & 12 \\
Phe & $1.64(2)$ & - & $7.15(7)$ & 9 \\
Lys & $1.79(2)$ & $1.00(1)$ & $12.73(13)$ & 16 \\
His & - & - & $1.00(1)$ & 1 \\
Arg & $2.97(3)$ & - & $4.12(4)$ & 7 \\
Trp & - & - & + & 1 \\
\hline Total & 48 & 22 & 165 & 235 \\
Position in & $1-50$ & $51-72$ & $73-248$ & \\
sequence & & & & \\
\hline
\end{tabular}


Isolation and sequence analysis of $\mathrm{CNBr}$ fragments in luffin-a

Following $\mathrm{CNBr}$ cleavage in $80 \%$ trifluoroacetic acid, the fragments were separated first by gel filtration on Bio-Gel P-30 column (Fig. 3 ) and then each fraction indicated by bar was purified by RP-HPLC on a $\mathrm{C}_{4}$ column using solvent system III, whereby three purified fragments designated as CB-I, CB-II, and CB-III were obtained. Table III summarizes their amino acid compositions. Since the $\mathrm{N}$-terminal sequence of CB-I was identical to that of luffin-a and CB-III did not contain homoserine, the three $\mathrm{CNBr}$-fragments were aligned to be (CB-I)-(CB-II)-(CB-III).

Analysis of the tryptic peptides from CB-I revealed it containing the tryptic peptides $T-1$ through $\mathrm{T}-4$ and a part of $\mathrm{T}-5$ (result not shown), indicating the linkage of (T-1)-(T-2)(T-3)-(T-4)-(T-5). Sequencing of fragment CB-II up to the 18 th step provided the linkage of (T-5)-(T-6). CB-III was sub-fragmented with $S$. aureus V8 protease, and as discernible in
Fig. 4, nine peptides (V-1-V-9) were obtained upon chromatography on a RP-HPLC $\mathrm{C}_{4}$ column by solvent system III. Their amino acid compositions are listed in Table IV. Sequencing of $\mathrm{V}-1$ and $\mathrm{V}-6$ indicated that they were a parts of T-6 and T-14, and those of V-2, V-3, V-4, $\mathrm{V}-5$ and $\mathrm{V}-7$ provided the linkages of (T-6)-(T-7)-(T-8), (T-8)-(T-9)-(T-10)-(T-11), (T-11)-(T-12), (T-12)-(T-13)-(T-14) and (T-14)(T-15)-(T-16), respectively. V-8 and V-9 were further fragmented with chymotrypsin and the resulting peptides were isolated by RP-HPLC using solvent system II. Their amino acid compositions and the sequences of peptides from $\mathrm{V}-8$ and $\mathrm{V}-9$ revealed the linkages of the tryptic peptides (T-16)-(T-17)-(T-18)-(T-19) and (T19)-(T-20)-(T-21)-(T-22), respectively (Fig. 6).

Thus, all the tryptic peptides (T-1-T-22) in luffin-a have been aligned as in Fig. 6 .

\section{Isolation of arginine-containing tryptic peptides} from succinylated luffin-a

Some of the alignments of the tryptic

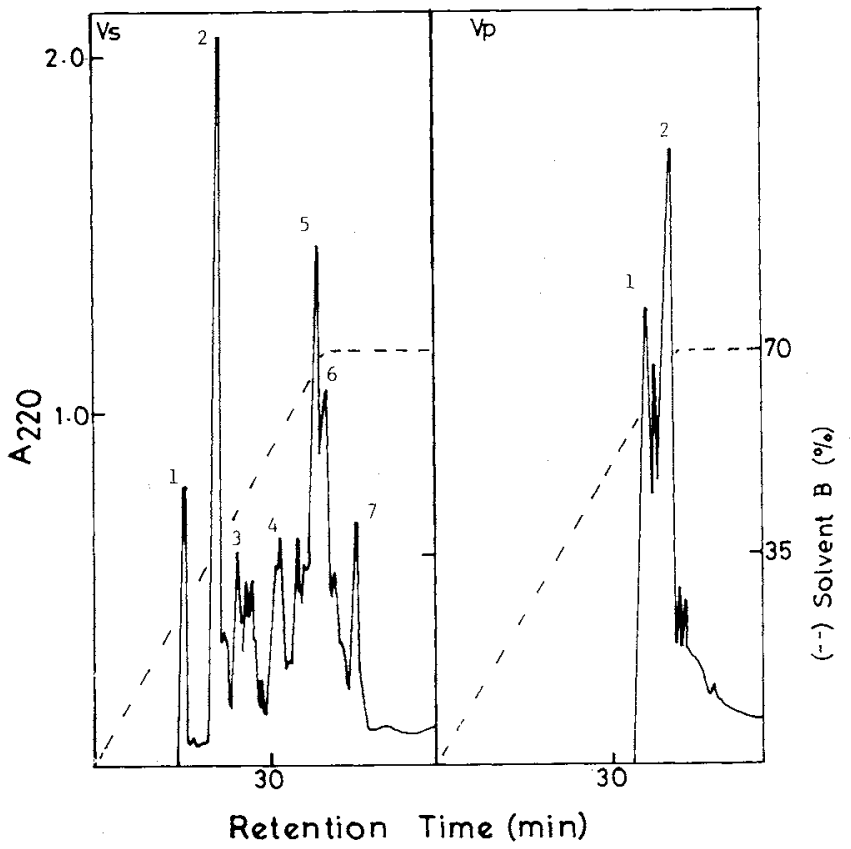

Fig. 4. RP-HPLC of the Peptides in Vs- and Vp-fractions from V8 Protease Digestion of CB-III on a Finepak $\mathrm{C}_{4}$ Column.

Elution was done with a linear gradient using solvent system III consisting of $0.1 \%$ TFA (solvent A) and $30 \% \mathrm{MeCN}$ in 2-PrOH (solvent B). 
Table IV. Amino Acid Compositions of the $S$. aureus Protease Peptides from Lufin-a The values in parentheses are calculated from the sequence.

\begin{tabular}{|c|c|c|c|c|c|c|c|c|c|c|}
\hline Amino acid & Vs-1 & Vs-2 & Vs-3 & Vs-4 & Vs-5 & $V_{s-6}$ & Vs-7 & $\mathrm{Vp}-1$ & $\mathrm{Vp}-2$ & Sum \\
\hline Asp & & & & $5.00(5)$ & $1.98(2)$ & $1.13(1)$ & $2.04(2)$ & $4.00(4)$ & $2.10(1)$ & 16 \\
\hline Thr & & $1.03(1)$ & & $4.10(4)$ & $0.90(\mathrm{~L})$ & $1.00(1)$ & $2.06(2)$ & $3.01(3)$ & $4.65(5)$ & 17 \\
\hline Ser & & & $1.28(1)$ & $2.56(3)$ & $1.69(2)$ & $2.73(3)$ & $3.60(4)$ & $0.86(1)$ & $1.69(2)$ & 16 \\
\hline Glu & $2.11(2)$ & $2.17(2)$ & $1.18(1)$ & $5.03(5)$ & $1.12(1)$ & $2.17(2)$ & $2.21(2)$ & $2.21(2)$ & $2.12(2)$ & 19 \\
\hline Pro & & & & $0.73(1)$ & & $1.02(1)$ & 1.19 (1) & & $1.72(2)$ & 5 \\
\hline Gly & $1.00(1)$ & $1.15(1)$ & & $2.18(2)$ & $1.20(1)$ & & $2.04(2)$ & & $1.19(1)$ & 8 \\
\hline Ala & & $2.18(2)$ & $1.16(1)$ & $1.85(2)$ & & $1.00(\mathrm{I})$ & $1.79(2)$ & $1.15(1)$ & $7.78(8)$ & 17 \\
\hline Val & & & & $2.66(3)$ & $0.90(\mathrm{l})$ & $1.10(1)$ & $1.98(2)$ & $3.59(4)$ & $0.81(1)$ & 12 \\
\hline Ile & $1.66(2)$ & $1.28(1)$ & $1.13(\mathrm{I})$ & $2.13(2)$ & & $1.93(2)$ & $0.91(1)$ & $1.96(2)$ & $2.78(3)$ & 14 \\
\hline Leu & & $1.24(1)$ & & $2.67(3)$ & $1.00(1)$ & $1.89(2)$ & $1.69(2)$ & $2.76(3)$ & $4.67(5)$ & 17 \\
\hline Tyr & & & $1.01(\mathrm{I})$ & & $1.89(2)$ & & $2.78(3)$ & 1.11 (1) & $0.87(1)$ & 8 \\
\hline Phe & & & $0.96(1)$ & $1.08(\mathrm{I})$ & $1.96(2)$ & & $1.12(\mathrm{l})$ & & $2.76(3)$ & 8 \\
\hline Lys & & $2.09(2)$ & $1.10(1)$ & $2.86(3)$ & & $0.90(1)$ & $1.80(2)$ & $3.00(3)$ & $1.00(\mathrm{I})$ & 13 \\
\hline His & & & & & & & & & $1.00(1)$ & 1 \\
\hline Arg & & $1.00(1)$ & $1.00(1)$ & 1.09 (1) & & 0.87 (1) & & & & 4 \\
\hline Trp & & & & + & & & & & & 1 \\
\hline Total & 5 & 11 & 8 & 36 & 13 & 16 & 26 & 24 & 37 & 176 \\
\hline $\begin{array}{l}\text { Position in } \\
\text { sequence }\end{array}$ & $168-172$ & $112-122$ & $160-167$ & 189-224 & $73-85$ & $173-188$ & $86-111$ & $225-248$ & $123-159$ & \\
\hline $\begin{array}{l}\text { Peptid } \\
\text { number }\end{array}$ & $V-6$ & $V-3$ & V-5 & V-8 & $V-1$ & $V-7$ & $\mathrm{~V}-2$ & V-9 & V-4 & \\
\hline
\end{tabular}

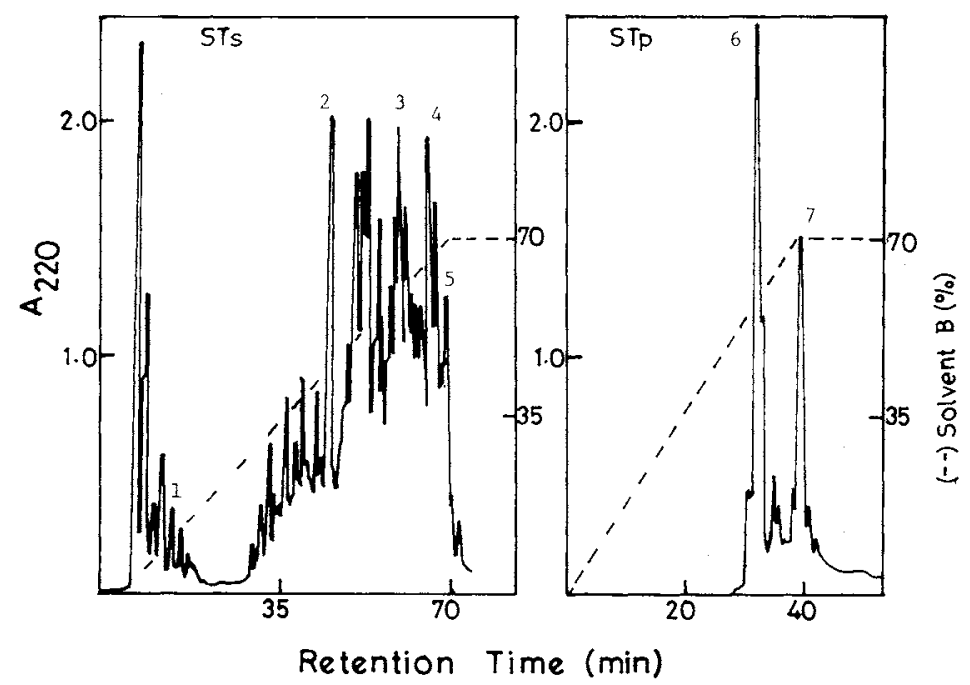

Fig. 5. RP-HPLC of the Tryptic Peptides from Succinylated Luffin-a.

STs-fraction was applied to a $\mathrm{C}_{4}$ column and eluted with solvent system I consisting of $5 \mathrm{~mm}$ phosphate buffer, pH 6.0 (solvent $\mathrm{A}$ ) and $60 \% \mathrm{MeCN}$ in the same buffer (solvent $\mathrm{B}$ ). The peptides in STp-fraction were separated on an Asahipak $C_{18}$ column with solvent system IV consisting of $5 \mathrm{~mm}$ ammonium bicarbonate solution (solvent $\mathrm{A}$ ) and $80 \% 2-\mathrm{PrOH}$ in the same solution (solvent $\mathrm{B}$ ).

peptides obtained above were also confirmed by analysis of tryptic peptides from the succinylated luffin-a. The STs- and STp- fractions from the tryptic digest of succinylated luffin-a were subjected to RP-HPLC with a Finepak $\mathrm{C}_{4}$ column using solvent system $\mathrm{I}$ and 
Table V. Amino Acid Compositions of the Selected Tryptic Peptides From Partially Succinylated Luffin-a

Numbers in parentheses are calculated from the sequences.

\begin{tabular}{|c|c|c|c|c|c|c|c|}
\hline Amino acid & STs- 1 & STs-2 & STs-3 & STs-4 & STs-5 & STp-1 & $\mathrm{STp}-2$ \\
\hline Asp & $1.13(1)$ & $1.09(1)$ & $1.23(1)$ & & $2.14(2)$ & $4.18(4)$ & $2.15(2)$ \\
\hline Thr & & $0.98(1)$ & $2.79(3)$ & & $1.87(2)$ & $2.75(3)$ & $4.05(5)$ \\
\hline Ser & & $7.20(7)$ & $2.09(2)$ & & $4.95(5)$ & $1.15(\mathrm{l})$ & $3.55(3)$ \\
\hline Glu & & & $1.89(2)$ & $3.21(3)$ & & $3.00(3)$ & $3.21(3)$ \\
\hline Pro & & & $0.78(1)$ & & $0.96(1)$ & & $1.94(2)$ \\
\hline Gly & & $1.83(2)$ & $3.18(3)$ & $1.10(1)$ & $2.13(2)$ & & $1.03(1)$ \\
\hline $\mathrm{Ala}$ & & & $2.05(2)$ & & $3.17(3)$ & $1.18(1)$ & $8.82(9)$ \\
\hline Val & 0.89 (I) & & $0.87(\mathrm{I})$ & & $0.93(1)$ & $4.68(5)$ & $1.13(1)$ \\
\hline Ile & & $0.74(1)$ & $1.70(2)$ & $2.69(3)$ & $1.16(1)$ & $1.66(2)$ & $2.78(3)$ \\
\hline Leu & & $1.84(2)$ & $2.13(2)$ & & $3.73(4)$ & $2.75(3)$ & $5.00(5)$ \\
\hline Tyr & & $0.88(1)$ & $2.05(2)$ & $0.87(1)$ & $0.97(1)$ & $0.92(1)$ & 1.17 (1) \\
\hline Phe & & $1.78(2)$ & & $0.93(1)$ & & & $2.64(3)$ \\
\hline Lys* & & $0.63(1)$ & $1.25(2)$ & 0.61 (1) & $0.73(1)$ & $1.96(3)$ & $0.73(1)$ \\
\hline His & & & & & & & $0.96(1)$ \\
\hline Arg & $1.00(1)$ & $1.00(1)$ & $1.00(1)$ & $1.00(1)$ & $1.00(1)$ & & $1.04(1)$ \\
\hline Total & 3 & 19 & 24 & 11 & 24 & 26 & 41 \\
\hline Position in sequence & $1-3$ & $4-22$ & $98-121$ & $163-173$ & $23-46$ & $223-248$ & $122-162$ \\
\hline Peptide number & ST-1 & ST-2 & $\mathrm{ST}-4$ & $\mathrm{ST}-6$ & $\mathrm{ST}-3$ & ST-7 & ST-5 \\
\hline
\end{tabular}

* Yield of succinylated-Lys was about $68 \%$ after $24 \mathrm{hr}$ of hydrolysis.

with an Asahipak $\mathrm{C}_{18}$ column using solvent system IV, respectively. As depicted in Fig. 5, RP-HPLC of the STs-fraction gave a number of peaks, probably due to incomplete succinylation, while that of the STp-fraction yielded only two peaks. In total, seven arginine-containing peptides (ST-1-ST-7) were obtained. Amino acid compositions of these peptides are outlined in Table V. Peptides ST-1 and ST-5 correspond to T-1 and T-4, while ST-2, ST-4 and ST-7 provided the linkage of (T-2)-(T-3), (T-13)-(T-14) and (T-11)-(T-12), respectively. Composition analysis and $\mathrm{N}$-terminal sequencing confirmed the alignment of (T-8)-(T-9)(T-10) in ST-3, and analysis of the chymotryptic peptides from ST-6 reestablished the alignment of (T-19)-(T-20)-(T-21)-(T-22).

\section{Amino acid sequence and carbohydrate composi- tion of luffin-a}

The amino acid sequence of luffin-a is summarized in Fig. 6. The sequence was obtained essentially from an analysis of the purified tryptic peptides. The overlapping se- quences were obtained from sequence analyses of the chymotryptic peptides, CNBrfragments or $S$. aureus $\mathrm{V} 8$ protease peptides of $\mathrm{CNBr}$-fragment. The amino acid composition calculated from the sequence is $\mathrm{Asp}_{9} \mathrm{Asn}_{14}$ $\mathrm{Thr}_{23} \mathrm{Ser}_{30} \mathrm{Glu}_{8} \mathrm{Gln}_{12} \mathrm{Pro}_{6} \mathrm{Gly}_{13} \mathrm{Ala}_{22} \mathrm{Val}_{17}$ Met $_{2} \mathrm{Ile}_{18} \mathrm{Leu}_{26} \mathrm{Tyr}_{13} \mathrm{Phe}_{10} \mathrm{Lys}_{16} \mathrm{His}_{1} \mathrm{Arg}_{7}$ $\operatorname{Trp}_{1}$, in good agreement with that determined after HCl-hydrolysis. The calculated molecular mass of the protein is $27,021 \mathrm{Da}$, which is slightly lower than that $(28 \mathrm{kDa})$ obtained by SDS-PAGE. ${ }^{7)}$ This discrepancy can be attributed to the presence of carbohydrate at positions Asn-28, Asn-33, Asn-77, Asn-84, Asn-206, and Asn-227 having the sequences of Asn-X-Thr/Ser. Indeed, these Asn residues could not be identified by the DABITC/PITC method, indicating the presence of attached oligosaccharide.

The sequence of luffin-a exhibits a random distribution of the 17 acidic and 24 basic residues all along the sequence. The presence of more basic residues over acidic residues corroborates its basic isoelectric point $(\mathrm{p} I>10){ }^{7)}$ 
DVRFSLSGS ${ }^{10} S T S Y S K F I G \stackrel{20}{D}$ T RKALPSNG TVYNLTILLS $S$ A S $\mathrm{T}-1 \mathrm{~T}-2$

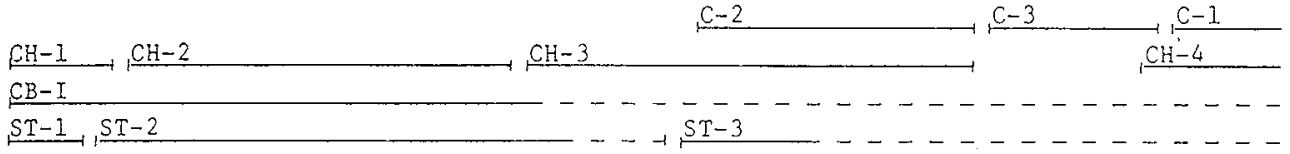

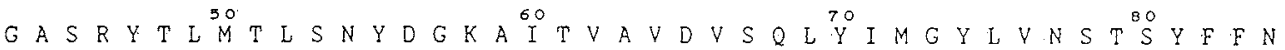

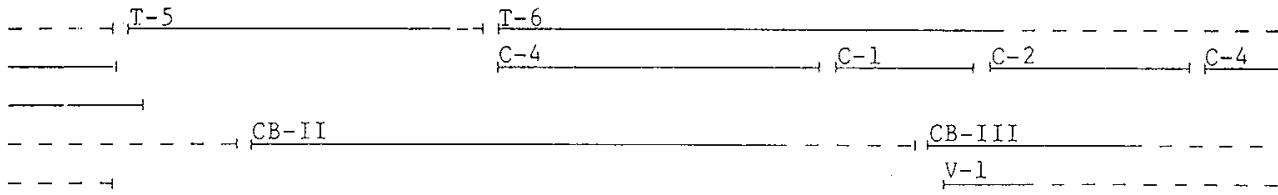
ES D A K $\stackrel{90}{L}$ A S Q Y Y F K G S ${ }^{200} I V T L P Y S G N^{2} Y^{\circ} E K L Q T$ T A A G K I R R E K I P L $\ldots-\cdots \rightarrow T-7 \quad \ldots-T-8$ $\longrightarrow$ CH-S $\mathrm{CH}-6$

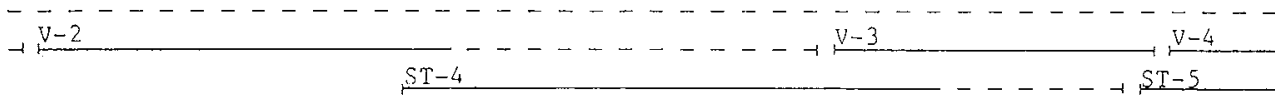

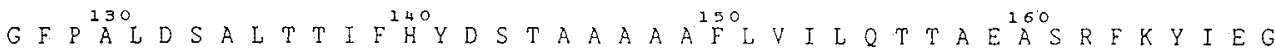

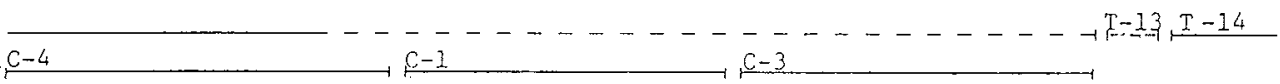

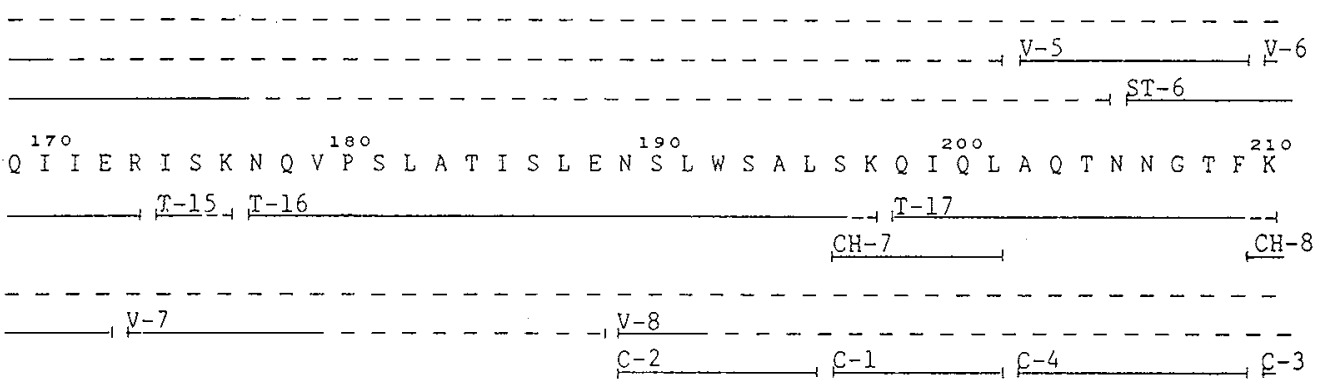

TPVV I T D D K $\stackrel{220}{G} Q R$ Y E I T N V T $S^{30} K V V T K N$ I Q L L L L N Y K Q N V A

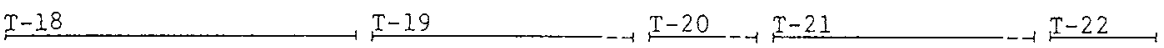

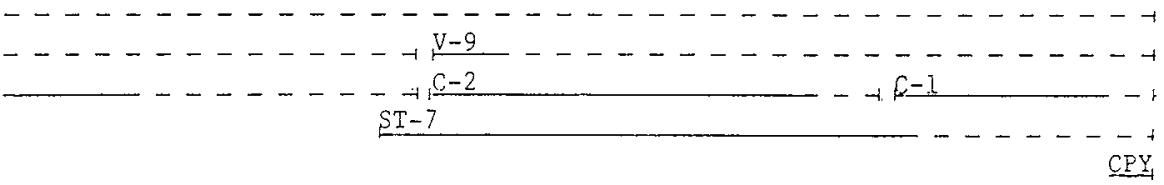

Fig. 6. Amino Acid Sequence of Luffin-a.

\section{Comparison of sequences}

The homology of luffin-a with the A-chain of ricin from Ricinus communis was examined by aligning closely related sequences for maximum identity using the computer program ALIGN. This comparison yielded an alignment 


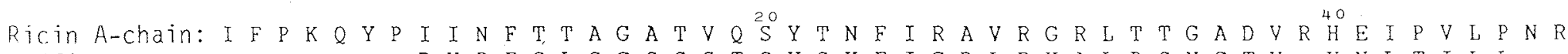

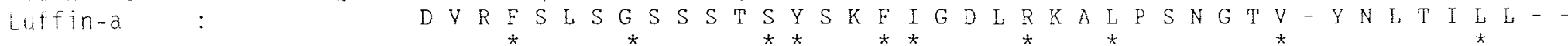

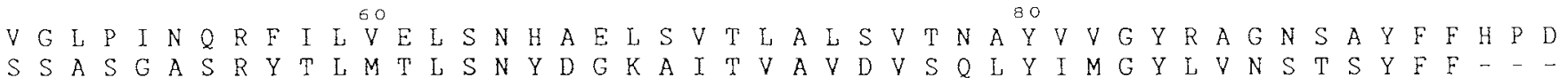

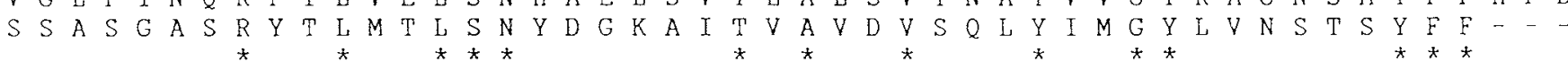

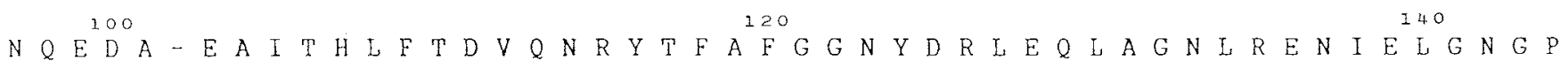
$N$ E S D A K L L A S Q $Y$ Y V F

L E E A I S A L Y Y Y S T G G T $\mathrm{T}$ Q L $\mathrm{L}$ D S A I T T T I F H Y

2002020040

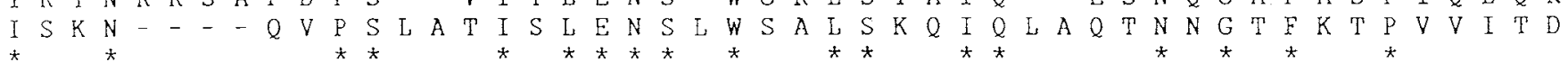

$$
260
$$

D G S K K F S S V Y

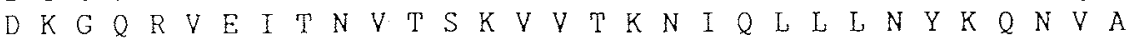

Fig. 7. Comparison of Amino Acid Sequence of Luffin-a with that of Ricin A-chain.

Identical residues are marked by asterisks $\left({ }^{*}\right)$. 
score of 23.4. As observed in Fig. 7, seventy-five amino acid residues comprising $33 \%$ of luffin-a are found to be identical and are being distributed all over the sequences except at the C-terminus 30 residues. The only Trp in both the proteins is conserved, while the only His-140 in luffin-a is not conserved in the ricin A-chain. The three-dimensional structure of ricin reveals a prominent cleft created by the interface of three distinct domains of Achain, ${ }^{18)}$ and it is proposed that one or more amino acids among the residues $167-215$ of the A-chain (168-219 in Fig. 7) lining this putative active-site cleft and conserved within the RIPs may be important in substrate binding and catalysis. ${ }^{19)}$ Inspection of the sequences in this region shows 23 identical residues including two tetrapeptide segments. Despite extensive studies through chemical modifications and site-directed mutagenesis, none of these 23 residues has been articulately assigned to be at the enzyme active-site. ${ }^{20-22)}$ Instead, Lys231 (254 in Fig. 7) of luffin-a, a residue in the non-conserved domain, has been demonstrated to be at or near the active-site. ${ }^{23}$ Furthermore, cleaving off the segment after Lys239 (244 in Fig. 7) of ricin A-chain also in the nonconserved C-terminus, produced an inactive species. ${ }^{24)}$

\section{References}

1) S. Olsnes and A. Pihl, Biochemistry, 12, 3121 (1973).

2) J. D. Irvin, T. Kelly and J. D. Robertus, Arch. Biochem. Biophys., 200, 418 (1980).

3) F. Stripe and L. Barbieri, FEBS Lett., 195, I (1986).
4) Y. Endo, K. Mitusi, M. Motizuki and K. Tsurugi, J. Biol. Chem., 262, 5908 (1987).

5) Y. Endo, K. Tsurugi and J. M. Lambert, Biochem. Biophys. Res. Commun., 130, 879 (1988).

6) K. Kishida, Y. Mausho and T. Hara, FEBS Lett., 153, 209 (1983).

7) M. Kamenosono, H. Nishida and G. Funatsu, Agric. Biol. Chem., 52, 1223 (1988).

8) M. R. Islam, H. Nishida and G. Funatsu, Agric. Biol. Chem., 54, 1343 (1990).

9) F. I. Lamb, L. M. Robert and J. M. Lord, Eur. J. Biochem., 148, 265 (1985).

10) R. Hayashi, S. Moore and W. H. Stein, J. Biol. Chem., 248, 2296 (1973).

11) W. A. Schroeder, J. B. Shelton and J. R. Shelton, Arch. Biochem. Biophys., 130, 551 (1969).

12) C. Y. Yang, E. Pauly, H. Kratzin and N. Hilschmann, Hoppe-Seyler's Z. Physiol. Chem., 362, 1131 (1981).

13) W. C. Mahoney, and M. A. Hermodson, J. Biol. Chem., 255, 11199 (1980).

14) H. Edelhoch, Biochemistry, 6, 1948 (1967).

15) J. Y. Chang, D. Braner and B. Wittmann-Lieboid, FEBS Lett., 93, 2205 (1978).

16) J. Y. Chang, E. H. Creaser and G. H. Huges, $J$. Chromatogr., 140, 125 (1977).

17) M. O. Dayhoff, W. C. Barker and L. T. Hunt, Methods Enzymol., 91, 524 (1983).

18) W. Monfort, J. E. Villafranca, A. F. Monzingo, S. R. Ernst B. Katzin, E. Rutenber, N. H. Xuong, R. Hamlin and J. D. Robertus, J. Biol. Chem., 262, 5398 (1987).

19) M. P. Ready, B. J. Katzin and J. D. Robertus, Proteins, 3, 53 (1988).

20) K. Watanabe and G. Funatsu, FEBS Lett., 204, 219 (1986).

21) D. Schlossman, D. Withers, P. Welsh, A. Alexander, J. Robertus and A. Frankel, Mol. Cel. Biol., 9, 5012 (1989).

22) J. L. Bradley and P. M. McGuire, Int. J. Peptide Protein Res., 35, 365 (1990).

23) K. Watanabe, Y. Suemasu and G. Funatsu, $J$. Biochem., 106, 977 (1989).

24) G. Funatsu, K. Watanabe and T. Utsumi, Agric. Biol. Chem., 53, 1173 (1989). 